\title{
P21. NK-cell dysfunction in human renal carcinoma reveals diacylglycerol kinase as key regulator and target for therapeutic intervention
}

\author{
P Prinz ${ }^{*}$, E Noessner \\ From 1st Immunotherapy of Cancer Conference (ITOC1) \\ Munich, Germany. 12-14 March 2014
}

NK cells are appreciated as antitumour effector cells in mouse models and human hematologic malignancies but their relevance in immunosurveillance of human solid tumours remains conflicting due to problems with in situ detection and reports of functional inactivity in the tumour milieu. The study was performed to identify mechanisms that impair NK-cell function in the tumour milieu and thereby identify therapeutic targets that allow recovery of NK-cell functionality.

We used in situ detection and flow cytometry to localise, quantify and profile NK cells of human clear cell renal cell carcinoma (ccRCC) tissue. Strategies were evaluated to reinstate functionality of tumour-derived NK cells. In vitro coculture models were applied to gain mechanistic insight into tumour-induced NK-cell alterations.

Tumour-resident NK cells, compared to NK cells from non-tumour kidney and PBLs, displayed conjoint phenotypic alterations and dysfunction induced by the tumour milieu, which were associated mechanistically with high levels of signaling attenuator diacylglycerol kinase (DGK)-a and blunted mitogen-activated protein kinase pathway activation (ERK1/2, JNK). Reinstating NK-cell functionality was possible by DGK-inhibition or brief IL-2-culture, interventions that de-repressed the ERK pathway. The extent of alteration and magnitude of recovery could be linked to NK-cell frequency within ccRCCinfiltrating lymphocytes, possibly explaining the observed survival benefit of patients with $\mathrm{NK}^{\text {high }}$ tumours.

DGK-mediated dampening of the ERK pathway ensuing in NK-cell dysfunction was identified as an important escape mechanism in ccRCC. DGK and the ERK pathway emerge as promising therapeutic targets to

Helmholtz Zentrum Muenchen, Molecular Immunology, Munich, Germany restore suppressed NK-cell activity for the improvement of antitumour immunity.

Published: 12 March 2014

doi:10.1186/2051-1426-2-S2-P12

Cite this article as: Prinz and Noessner: P21. NK-cell dysfunction in human renal carcinoma reveals diacylglycerol kinase as key regulator and target for therapeutic intervention. Journal for ImmunoTherapy of Cancer 2014 2(Suppl 2):P12.
Submit your next manuscript to BioMed Central and take full advantage of:

- Convenient online submission

- Thorough peer review

- No space constraints or color figure charges

- Immediate publication on acceptance

- Inclusion in PubMed, CAS, Scopus and Google Scholar

- Research which is freely available for redistribution
( Biomed Central 